\title{
THE CLINICAL OUTCOME AND THERAPEUTIC TREATMENT OF A PATIENT WITH DOUBLE SERONEGATIVE MYASTHENIA GRAVIS
}

Ana Azanjac, Gordana Tončev, Katarina Vesić, Aleksandar Gavrilović, Tatjana Bosković Matić and Svetlana Miletić Drakulić Clinic of neurology, Clinical center Kragujevac, Zmaj Jovina 30, 34000 Kragujevac, Serbia

\section{KLINIČKI ISHOD I TERAPIJA KOD BOLESNIKA SA DVOSTRUKO NEGATIVNOM MYASTHENIOM GRAVIS}

\begin{abstract}
We reported a case of a 22-year-old male patient with swallowing difficulties and double vision. He was diagnosed on the basis of a positive pharmacological test, damage to the postsynaptic neuromuscular junction and computed tomography of the thorax. Tests for antibodies targeted to acetylcholine receptors and to muscle-specific tyrosine kinase were negative. A partial improvement in neurological findings following treatment with pyridostigmine bromide, cyclosporine and methylprednisolone was notedadministered. The patient responded favourably to plasma exchange with a withdrawal of all clinical symptoms, confirming the hypothesis that humoral factors may underlie the pathogenesis of double-negative $M G$.
\end{abstract}

Keywords: seronegative Myasthenia gravis, anti-LRP4 autoantibodies

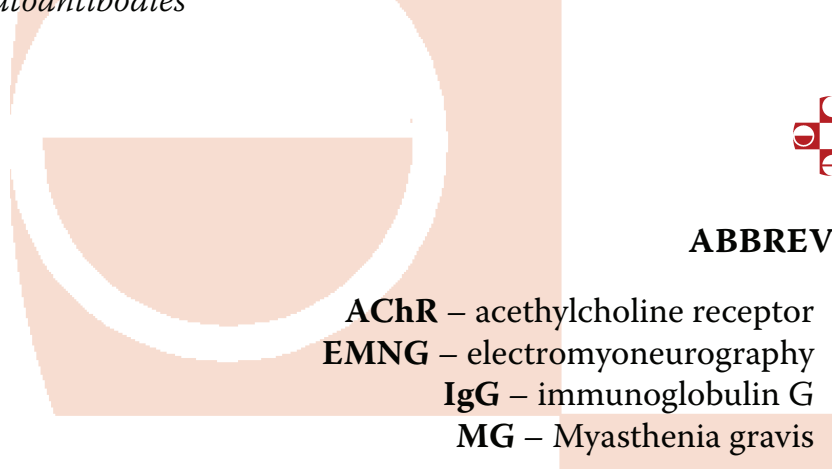

\section{INTRODUCTION}

Myasthenia gravis (MG) is an autoimmune disease affecting the neuromuscular junction of skeletal muscle, and in most patients, it is caused by acetylcholine receptor (AChR)-targeted antibodies (1). These antibodies, of the IgG isotype, are detected in $80-90 \%$ of generalised MG and in 50-70\% of ocular MG. The remaining $10-20 \%$ of MG patients are AChR antibody-negative (seronegative). In $40 \%$ of patients with seronegative MG, IgG antibodies targeted to the muscle-specific kinase (MuSK)

\section{SAŽETAK}

Prikazali smo slučaj 22-godišnjeg muskarca sa kliničkom slikom otežanog gutanja $i$ dvoslika. Bolest myasthenia gravis (MG) je dijagnostikovana na osnovu pozitivnog faramakološkog testa, pozitivnog testa neuromišićne transmisije, kompjuterizovane tomografije medijastinuma. Antitela protiv acetilholinskog receptora (AChR) i antitela protiv mišićno specifičnog receptora za tirozin kinazu (MuSK). bila su negativna. Zabeleženo je delimično poboljšanje u neurološkom nalazu na ordiniranu terapiju Piridostigminom, Ciklosporinom, kortikosteroidima. Bolesnik je imao povoljan odgovor na izmenu plazme sa povlačenjem svih kliničkih siimptoma što potvrdjuje hipotezu o učešću humoralnih faktora u patogenezi dvostruko negativne MG.

Ključne reči: seronegativna Myasthenia gravis, antiLRP4 antitela
MuSK - muscle-specific tyrosine kinase

LRP4 - low density lipoprotein

receptor-related protein 4

SNMG - seronegative Myasthenia gravis 


\section{CASE REPORT}

In September 2011, a 22-year-old male patient was admitted to the Department of Neurology in Kragujevac, who had difficulty in swallowing and double vision. These symptoms had occurred on the day prior to admission. Neurological examination upon admission showed diplopiae when looking up and dysphagia with nasal regurgitation of liquids together with slurred speech. A fatigue test was positive. Motor power to the neck and proximal muscles of the upper and lower limbs was intact.

As part of the diagnostic procedures, a pyridostigmine test was performed, which was positive. Antibodies to acetylcholine receptors and to muscle-specific tyrosine kinase were not detected (AChR antibodies less than $0.1 \mathrm{nmol} / \mathrm{l}$ and anti-MuSK antibodies less than 0.01). Computed tomography of the thorax showed inhomogeneous density with increased fat tissue in smaller areas of the thymus. A test of neuromuscular transmission (TNT) in the n. axillaris-m. deltoideus 1 . dex. and n. facialis-m. nasalis 1 . dex. system performed upon admission was normal.

After three weeks, a second test of neuromuscular transmission in the n. axillaris - $\mathrm{m}$. deltoideus 1 . dex system was performed. A rapid nerve conduction protocol was used at a, frequency of 1-3 Hz. That study indicated a marked decrease in amplitude of action potentials (39\%-54\%) at all stimulations and demonstrated accumulated damage to the postsynaptic neuromuscular junction level. Three days after admission, the patient developed proximal weakness of the neck anteflexors and proximal weakness of the musculature of the lower limbs. On admission, the following therapy was administered: tbl. Pyridostigmine bromide at a dose of $60 \mathrm{mg}$ 1 to 6 hours, sol. Cyclosporine 2x1, $5 \mathrm{ml}$, amp. Methylprednisolone at a dose of $80 \mathrm{mg} /$ day, three times a day infusions, amp. Prostigmin with $1.5 \mathrm{mg}$, amp. Atropine $0.5 \mathrm{mg}$ and a partial improvement in neurological findings was observed. Plasmapheresis was then administered, and six therapeutic plasma exchanges were performed on the second day after admission. The patient responded favourably to plasma exchange, and all clinical symptoms withdrew. After a few days of plasma exchange, the symptoms reappeared and progressed in intensity with a worsening response to therapy observed. On the ninth day of hospitalisation, the patient developed respiratory insufficiency. The patient then received intravenous immunoglobulin (Intratect) at $0.4 \mathrm{~g} / \mathrm{kg}$ daily for 5 days, and a partial response to therapy was observed. Control EMNG on the $21^{\text {st }}$ day after symptom onset showed damage to the postsynaptic neuromuscular junction.

A thymectomy was performed during the fourth month of disease. A histological examination of thymic tissue indicated hyperplasia of the thymus.

\section{DISCUSSION}

Myasthenia gravis (MG ) is an autoimmune disease characterised by a defect in synaptic transmission at the neuromuscular junction that leads to fluctuating muscle weakness (3).The term seronegative myasthenia gravis (SNMG) refers to a generalised disease without detectable anti-acetylcholine receptor (anti AChR) antibodies (4). However, approximately $10 \%$ of patients with generalised myasthenia gravis show no antibodies to AChR or MuSK and are described as having double seronegative MG (5).

Up to $66 \%$ of these patients (double seronegative patients) show a low titre of low affinity antibodies targeted to AChRs. After 12 months, 15,2\% of initially seronegative patients had become seropositive, yielding a seronegativity rate of $8,2 \%$. Of seronegative patients not receiving immunosuppressants, $38 \%$ were MuSK antibody-positive and $43 \%$ were seropositive for non-muscle autoantibodies (6). In the Serbian population, anti-AChR antibodies were detected in sera of $84,1 \%$ of patients, whereas $15,9 \%$ of patients did not show these antibodies (AChR antibody-negative patients). Of these AChR antibody-negative patients, anti-MuSK antibodies were detected in $36,4 \%$ of patients (7).

In our case, we report upon a male patient with double seronegative myasthenia gravis, who showed no detectable anti-AChR or anti-MuSK antibodies. This profile follows the distribution of gender in SNMG with anti-MuSK antibodies, where a higher prevalence is observed in females (3). Seronegative myasthenia gravis is more similar to acetylcholine receptor antibody-positive myasthenia gravis than MuSK antibody-positive myasthenia gravis with respect to clinical features, immunosuppressive treatments and thymic pathology (8); however, subtle differences exist in age at onset, maximum severity and regional distribution of myasthenic weakness (1).

In MuSK-negative patients, the clinical profile is more heterogeneous. The majority of patients show mild disease. Limb muscles are more commonly affected, and bulbar signs are both less frequent and less severe than in MuSK-positive subjects (9). Involvement of the bulbar musculature was observed in 60,1\% of MuSK-positive patients, 35,2\% of AChRpositive and $23,8 \%$ of double negative patients at onset. The number of patients who showed bulbar symptoms at the final observation was $29,1 \%$ in the MuSK-positive group vs. only $6,7 \%$ in the double negative group (10). In our patient, his disease began with acute bulbar musculature weakness with ptosis and diplopia. Additionally, in seronegative MuSK patients, respiratory crises are rare, whereas our patient developed respiratory failure on the ninth day of disease.

We noted a good response of our patient to pharmacological tests and a positive pyridostigmine test for neuromuscular junction. The single fibre EMG test is particularly useful in complete seronegative MG cases in which the RNS test is negative; however, this test is not used in our institution (11). A recent report indicated that more than $60 \%$ of AChR and MuSK antibody-negative MG patients show low-affinity antibodies to AChRs. These data indicate that at least some double seronegative MG patients have antibodies directed against AChR that are not detected by routine immunoprecipitation assays. These findings strongly imply that the SNMG antibodies are directed towards AChRs but that they 
bind appreciably only when the AChRs are packed densely in relatively immobile clusters. Some evidence has suggested that co-expression with MuSK and Dok-7 increases further the sensitivity of the test, leaving open the possibility that intracellular modifications of either AChRs or MuSKs or changing the packing geometry of the clusters may influence the binding of these low-affinity antibodies (12).

Identification of LRP 4 as the MuSK-binding agrin receptor in skeletal muscle tissue suggested the possibility that autoantibodies for this membrane protein may underlie myasthenia gravis (13). Consistent with this hypothesis, antibodies targeted against the extracellular portion of LRP4 have recently been detected in 9 out $300 \mathrm{AChR}$ and MuSK seronegative MG patients. LRP4 is a member of the low density lipoprotein receptor-related protein family of transmembrane proteins and has important functions during development and morphogenesis of limbs and the ectodermal organs, lungs and kidneys $(14,15)$. In adult skeletal muscle, LRP4 is specifically expressed at the neuromuscular junction. In particular, this result indicates that autoantibodies are targeted against LRP4 in approximately $50 \%$ of double seronegative MG causes, which is considerably higher than the $3 \%$ previously reported (3). All patients improved following treatment with a combination of AChE inhibitors and two or more forms of immunotherapy, and all achieved stable clinical and pharmacological remission.

Studies investigating therapeutic responses in doublenegative MG support the hypothesis of humoral factors underlying the pathogenesis of this form of MG. Double seronegative groups show a higher percentage good outcomes and lower maintenance prednisolone doses than AChR- or MuSK-positive groups. The good outcome in the SN patients was unrelated to the composition of the group because even the most severely involved patients showed good outcomes (16). A classification as being seronegative MG should be reserved for non-immunosuppressed patients with generalised MG who lack muscle AChR binding, AChR modulating or MuSK antibodies at presentation and after a follow-up of at least 12 months (6). Here, in our case study, we have presented a patient with partial improvement of neurological findings upon administration of administered pyridostigmine bromide, cyclosporine and methylprednisolone. The patient responded favourably to plasma exchange, with the withdrawal of all clinical symptoms, confirming the hypothesis that humoral factors are involved in the pathogenesis of double negative MG.

\section{REFERENCES:}

1.F Romi, J.A.Aarli and N.E. Gilhus. Seronegative myasthenia gravis: disease severity and prognosis. European Journal of Neurology 2005; 12: 413-418.
2. A.Vincent, J.Bowen,J.Newsom-Davis and J.McConvillie. Seonegative generalized mysthenia gravis: clinical features, antibodies and their target. Lancet Neurology 2003; 2: 99-106.

3. Pevzner A, Schoser B, Peteres K, et all. Anti-LRP4 autoantibodies in AchR- and MuSK antibody negative myasthenia gravis. J Neurol 2012; 259(3): 427-35.

4. Liyanage Y, Hoch W, Beeson D, Vincet A. The agrin/ muscle specific kinase pathway. New target for autoimmune and genetic disorders at the neuromuscular junction. Muscle Nerve 2002; 25: 4-16.

5. Farrugia ME, Vincent A. Autoimmune mediated neuromuscular junction defects. Curr Opin Neurol 2010; 23: 489-495.

6. Chan et all. Frequency of seronegativity in adult-acquired generalized myasthenia gravis. Muscle Nerve. 200736 (5):651-8

7. Nikolić A, Djukić P, Basta I, et all. The predictive value of the presence of different antibodies and thymus pathology to the clinical outcome in patients with generalized myasthenia gravis. Clinical Neurol Neurosurg. 2013115 (4):432-7

8. Evoli A, Tonali P, Padua L, et all. Clinical correlates with anti MuSK antibodies in generalized seronegative myasthenia gravis. Brain 2003; 126: 2304-2311.

9. Kim N, Stiegler AL, Cameron TO, et all. LRP 4 is a receptor for agrin and forms a complex with MuSK. Cell 2008; 135:334-342.

10. Baggi F, Andereetta F, Maggi L et all. Complete stable remission and autoantibody specificity in myasthenia gravis. Neurology 2013; 8:80 (2): 188-95

11. Witoonpanich et all. Electrophysiological and immunological study in myasthenia gravis: diagnostic sensitivity and correlation. Clin Neurophysiol. 2011122 (9): 1873-7

12. Leite MI, Jacob S, Viegas S, et all. IgG1 antibodies to acetylcholine receptors in seronegative myasthenia gravis. Brain 2008; 131: 1940-1952

13. Higuchi O, Hamuro J, Motomura M, Yamanashi Y. Autoantibodies to low-denssity lipoprotein receptor-related protein 4 in myasthenia gravis. Ann Neurol 2011; 69: 418-422.

14. Simon-Chazottes D, Tutois S, Kuehn M,et all. Mutations in the gene encoding the low-density lipoprotein LRP4 cause abnormal limb development in the mouse. Genomics 2006; 87: 673-677.

15. Courtney M. Karner, Martin F. Dietrich, Eric B. Johnson, et all. LRP4 regulates initiation of ureteric budding and is crucial for kidney formation of the neuromuscular junction. Development 2010; 133: 4993-500

16. Deymeer F, Gungor-Tuncer O, Yilmaz V, et al. Clinical comparasion of anti-MuSK-vs anti-AChR-positive and seronegative myasthenia gravis. Neurology 2007;68:609-611 